\title{
BMJ Open Association of dental and periodontal disease with chronic kidney disease in patients of a single, tertiary care centre in Thailand
}

\author{
R Ausavarungnirun, ${ }^{1} \mathrm{~S}$ Wisetsin, ${ }^{2} \mathrm{~N}$ Rongkiettechakorn, ${ }^{1} \mathrm{~S}$ Chaichalermsak, ${ }^{3}$ \\ U Udompol, ${ }^{4}$ M Rattanasompattikul ${ }^{1}$
}

To cite: Ausavarungnirun $\mathrm{R}$, Wisetsin S,

Rongkiettechakorn $\mathrm{N}$, et al. Association of dental and periodontal disease with chronic kidney disease in patients of a single, tertiary care centre in Thailand. BMJ Open 2016:6:e011836. doi:10.1136/bmjopen-2016011836

- Prepublication history for this paper is available online. To view these files please visit the journal online (http://dx.doi.org/10.1136/ bmjopen-2016-011836).

Received 13 March 2016 Revised 3 May 2016 Accepted 28 June 2016

CrossMark

For numbered affiliations see end of article.

\section{Correspondence to}

Dr Manoch

Rattanasompattikul;

manoch.rat@mahidol.ac.th

\section{ABSTRACT}

Background: Several studies have shown an association between oral diseases and chronic kidney disease (CKD), and regular oral care may be an important strategy for reducing the burden of CKD. The objective of this study was therefore to evaluate the association between dental and periodontal diseases in Thai patients with various stages of CKD. Methods: This was designed as a cross-sectional study and was performed between 2011 and 2012. The inclusion criteria were age $>20$ years and a diagnosis of CKD for at least 90 days. Data from medical records were collected, clinical oral examination was performed, and data were statistically analysed.

Results: A total of 129 patients with different stages of CKD were included. Ninety-eight $(76 \%)$ were men. The age range was $30-86$ years. The Decay, Missing and Filling Tooth Index and the number of missing teeth were higher in the group with moderate CKD than in the control group ( 21 vs $17.5, p=0.045,13$ vs 8 $p=0.01$, respectively). Serum albumin levels decreased when estimated glomerular filtration rate (eGFR) was in decline $(\gamma=0.33 ; p=0.002)$. Severe periodontitis was significantly higher in the 'more severe CKD group' (eGFR $<60 \mathrm{~mL} / \mathrm{min} / 1.73 \mathrm{~m}^{2}$ ) than in the 'less severe CKD group' (eGFR $60-90 \mathrm{~mL} / \mathrm{min} / 1.73 \mathrm{~m}^{2} ; 24 \%$ vs $9 \%, p=0.03$ ). Severe periodontitis, eGFR $<30 \mathrm{~mL} / \mathrm{min} /$ $1.73 \mathrm{~m}^{2}$ and brushing teeth more than once a day were associated with hypoalbuminaemia (defined as $<3.8 \mathrm{~g} / \mathrm{dL}$ ) (OR (95\% Cl) 5.88 (1.64 to 21.11), 5.80 (1.58 to 21.35 ) and 0.16 (0.05 to 0.60$)$, respectively). Conclusions: Severe periodontal diseases were more prevalent in patients with more severe CKD than in those with less severe CKD. The novel association of serum albumin levels with periodontal status was demonstrated in progressive stages of CKD. Dental intervention may be beneficial from the early stages of CKD.

\section{INTRODUCTION}

Chronic kidney disease (CKD), the gradual and usually permanent reduction of the glomerular filtration rate (GFR) of the

\section{Strengths and limitations of this study}

- This cross-sectional study demonstrates that serum albumin levels correlated with progressive stages of chronic kidney disease and severe periodontal status.

- The laboratory measurements were uniform because all were obtained from a single facility.

- Performance in a single centre and a relatively small, but comparable with most previous reports, number of enrolled patients.

- We could not consider the educational levels of these patients or their socioeconomic statuses, which might affect periodontal status.

- We did not record other comorbidities, such as malabsorption, that could cause hypoalbuminaemia.

kidneys, leads to increases in serum creatinine and blood urea nitrogen (BUN) levels, resulting in uraemia or azotaemia. Common causes of CKD are hypertension, diabetes mellitus, chronic glomerulonephritis, obstructive uropathy, autoimmune disease and obesity. ${ }^{1-6}$ Uraemia develops and adversely affects every system of the body. ${ }^{7}$ Systemic abnormalities, such as anaemia, platelet disorder and hypertension, can be observed in individuals with chronic renal disease. $^{7}$ Patients with end-stage renal disease (ESRD) who are receiving haemodialysis experience a greatly increased rate of atherosclerotic complications. ${ }^{8}$ C-reactive protein (CRP) in malnutrition, the major acute phase protein in man, predicts all-cause and cardiovascular mortality in patients with ESRD receiving maintenance haemodialysis (MHD) therapy. ${ }^{9-13}$ The goal of treatment is to maintain kidney function and homoeostasis for as long as possible. ${ }^{6}$

Oral manifestations of chronic renal disease are common during the progression 
of uraemia. They may present as unique signs of multisystem diseases affecting the kidney or as common oral pathologies found with increased prevalence in patients with ESRD. ${ }^{9} 14 \quad 15$ Uraemic patients have more dental problems than healthy controls in oral mucosa, teeth, salivary glands ${ }^{16}$ and jaw bones, problems that seem to develop before dialysis. ${ }^{17} 18$ Xerostomia, uraemic stomatitis, periodontal disease and maxillary and mandibular radiographic alterations can be observed in patients with chronic renal failure. ${ }^{14}$ Periodontal diseases are highly prevalent among patients with chronic renal failure, ${ }^{8} 17 \quad 1920$ specifically gingivitis, excessive plaque formation and poor oral hygiene in uraemic patients; ${ }^{21}$ however, there are previous reports that periodontal diseases and other dental problems, such as loss of teeth, periapical lesions and mucosal lesions, are contradictory findings. ${ }^{22}{ }^{23}$ Other studies have confirmed that periodontal health is poor in haemodialysis patients and that it correlates with markers of malnutrition and inflammation. ${ }^{24}{ }^{25}$ We could not find any study that evaluated the oral health of Thai patients with various stages of CKD. The objective of this study was therefore to evaluate the association between dental and periodontal diseases in Thai patients with various stages of CKD, who were treated at the Golden Jubilee Medical Center, Mahidol University, Thailand from 2011 to 2012.

\section{SUBJECTS AND METHODS Patients}

This was designed as a cross-sectional study and performed at the Golden Jubilee Medical Center, Mahidol University, Thailand during 2011-2012. The project was approved by the Mahidol University Institutional Review Board (MU-IRB 2011/102.1005). Written informed consent to participate in the trial was obtained from all patients. The Modification of Diet in Renal Disease Study equation was calculated as follows: estimated GFR $\left(\right.$ eGFR; $\left.\mathrm{mL} / \mathrm{min} / 1.73 \mathrm{~m}^{2}\right)=175 \times\left(\mathrm{S}_{\mathrm{cr}}\right)^{-1.154} \times(\text { Age })^{-0.203} \times$ $(0.742$ if female $) \times(1.212$ if African-American $) ;{ }^{26}$ during the period of this study, the CKD Epidemiology Collaboration equation was not the most widely used equation. The inclusion criteria were patients who had been diagnosed with CKD for at least 90 days and age $>20$ years. The study groups were divided by eGFR into mild CKD group (eGFR $60-90 \mathrm{~mL} / \mathrm{min} / 1.73 \mathrm{~m}^{2}$; group 1 ), moderate CKD group (eGFR $30-60 \mathrm{~mL} / \mathrm{min} / 1.73 \mathrm{~m}^{2}$; group 2), and severe CKD group (eGFR $<30 \mathrm{~mL} / \mathrm{min} / 1.73 \mathrm{~m}^{2}$; group 3). Patients on MHD were also included in this study. The exclusion criteria were any systemic disease that could acutely affect the GFR (rapid progressive glomerulonephritis, active glomerular diseases, pregnancy) and/or oral health status (immunodeficiency syndrome, recurrent or active cancer) or any medication that could affect oral health status, such as immunosuppressive drugs (corticosteroid drugs or chemotherapy). After application of the inclusion and exclusion criteria, 129 patients were recruited for this study.

\section{Clinical and demographic measures}

The data used in this study were: (1) responses to questions on age, gender, smoking, comorbidities such as diabetes and/or hypertension, and CKD aetiologies; (2) laboratory assays of serum BUN, serum creatinine, glycated haemoglobin $\left(\mathrm{HbA}_{1} \mathrm{C}\right)$, fasting plasma glucose, serum total cholesterol, serum high-density lipoprotein (HDL) cholesterol, serum low-density lipoprotein (LDL) cholesterol, serum albumin, serum uric acid and haematocrit; and (3) assessment of dental and periodontal status by two dentists who were blinded to CKD status. Both dentists were trained in the Decayed, Missing or Filled Teeth (DMFT) and Community Periodontal Index (CPI) systems and were familiarised with the standard protocol before the study started. The numbers of DMFT, according to the criteria recommended by the WHO, were recorded. ${ }^{27} \mathrm{~A}$ tooth was classified as: decayed when there was a soft cavity or undermined enamel on the tooth surface; filled when restored with dental materials; missing when indicated by routine dental examination. The periodontal status was assessed using the CPI system: ${ }^{28}$ a score of $0=$ healthy, $1=$ bleeding, $2=$ calculus, $5=$ calculus and bleeding immediately after probing, 3=pocket $4-6 \mathrm{~mm}$, and $4=$ pocket $>6 \mathrm{~mm}$. Pocket depths were measured using a standard periodontal probe at six sites around each representative tooth in each sextant and represented the distance from the gingival margin to the deepest site of the gingival sulcus. Six sextants containing at least two functional teeth were assigned a code number. The condition of the worst-affected site in each sextant was recorded. Periodontal health was transformed from the CPI score to fair (CPI score of 1, 2 or 5), moderate (CPI score of 3 ) or severe (CPI score of 4) periodontal status. Fair periodontal status was clinically diagnosed as gingivitis, while moderate and severe periodontal statuses were clinically diagnosed as periodontitis.

\section{Laboratory measures}

Blood samples were drawn using uniform techniques and all laboratory values were obtained by automated and standardised methods at the International Center for Medical and Radiological Technology Laboratory Department of the Golden Jubilee Medical Center.

\section{Description of risk factors}

The principal exposure or predictor for this analysis was periodontal status based on a clinical examination. ${ }^{29}$ Other traditional and suspected non-traditional risk factors for CKD included in the analyses were age, gender, health status (diabetes mellitus and hypertension), health behaviour (smoking) and biomarker levels (total cholesterol, HDL cholesterol and LDL cholesterol). Outcomes or dependent variables of this study were dental examination results such as missing teeth, filled teeth, DMFT Index and periodontal status of patients with CKD. 


\section{Statistical methods}

After dividing subjects into a low renal function group with moderate CKD (eGFR $30-60 \mathrm{~mL} / \mathrm{min} / 1.73 \mathrm{~m}^{2}$ ) and severe CKD $\left(\mathrm{eGFR}<30 \mathrm{~mL} / \mathrm{min} / 1.73 \mathrm{~m}^{2}\right)$ for the study group and mild CKD (eGFR $60-90 \mathrm{~mL} / \mathrm{min}$ / $1.73 \mathrm{~m}^{2}$ ) for the control group, we compared blood chemistry (BUN, creatinine, fasting blood sugar, \% $\mathrm{HbA}_{1} \mathrm{C}$, total cholesterol, LDL cholesterol, HDL cholesterol, triglyceride, uric acid, serum albumin, haematocrit) among the three groups using the analysis of variance test. The median number for the DMFT Index was calculated for each CKD group and compared among the groups using the Mann-Whitney test and among all the groups by the Kruskal-Wallis test. The $\chi^{2}$ test was used to study the proportion of periodontal disease and brushing behaviour between two and three groups. The data obtained were analysed using the SPSS V.16 statistical package. $\mathrm{p}<0.05$ indicated significance. All tests were two-sided.

\section{RESULTS}

Table 1 presents the essential characteristics of the study population and their unadjusted associations with the CKD groups. Group 3 had the most severe CKD and higher levels of blood creatinine but lower albumin levels $(p<0.05)$ than the other two groups. The levels of serum albumin also decreased when eGFR was in decline $(\gamma=0.33 ; \mathrm{p}=0.002)$. Figure 1 shows the unadjusted correlation coefficients of serum albumin and eGFR. Despite the high prevalence of inherited autosomal recessive blood disorders, such as thalassaemia, we still observed the lowest haematocrit in group 3.

Twenty-seven per cent of the patients in this study had severe CKD, 37\% moderate CKD, and 36\% mild CKD; $76 \%$ of the total sample was male. There was no statistically significant difference between the groups concerning gender. The mean $\pm \mathrm{SD}$ age of the participants was $61 \pm 11$ years. There was a significant difference between the three groups with respect to age; the mean age of the patients with severe CKD was lowest ( $56 \pm 12$ years). Underlying kidney diseases were different and underestimated among groups. Diabetes kidney disease was not the most common aetiology, but this study showed a non-statistical difference in diabetes mellitus type 2 as a comorbid disease. This may be because of inadequate kidney biopsy proof.

An independent association was observed between poorer dental health and mortality for adult haemodialysis patients, and specific oral hygiene practices were linked to better survival. We found that, in the most severe CKD group (group 3), patients had worse brushing behaviour than the other groups: $11 \%$ did not brush their teeth, but this difference was not significant $(\mathrm{p}=0.05)$.

The DMFT Index is shown in table 2. We noticed a difference between the focus group (groups 2 and 3) and the mild CKD group (group 1) ( $\mathrm{p}=0.85$ and 0.045 ,

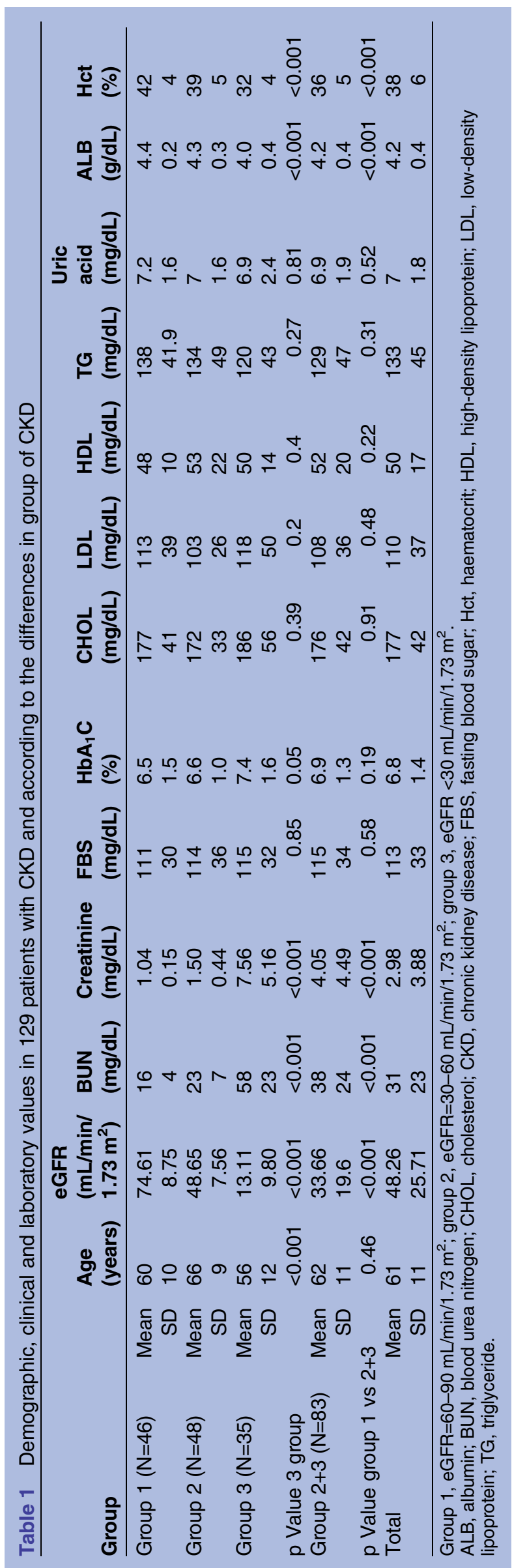



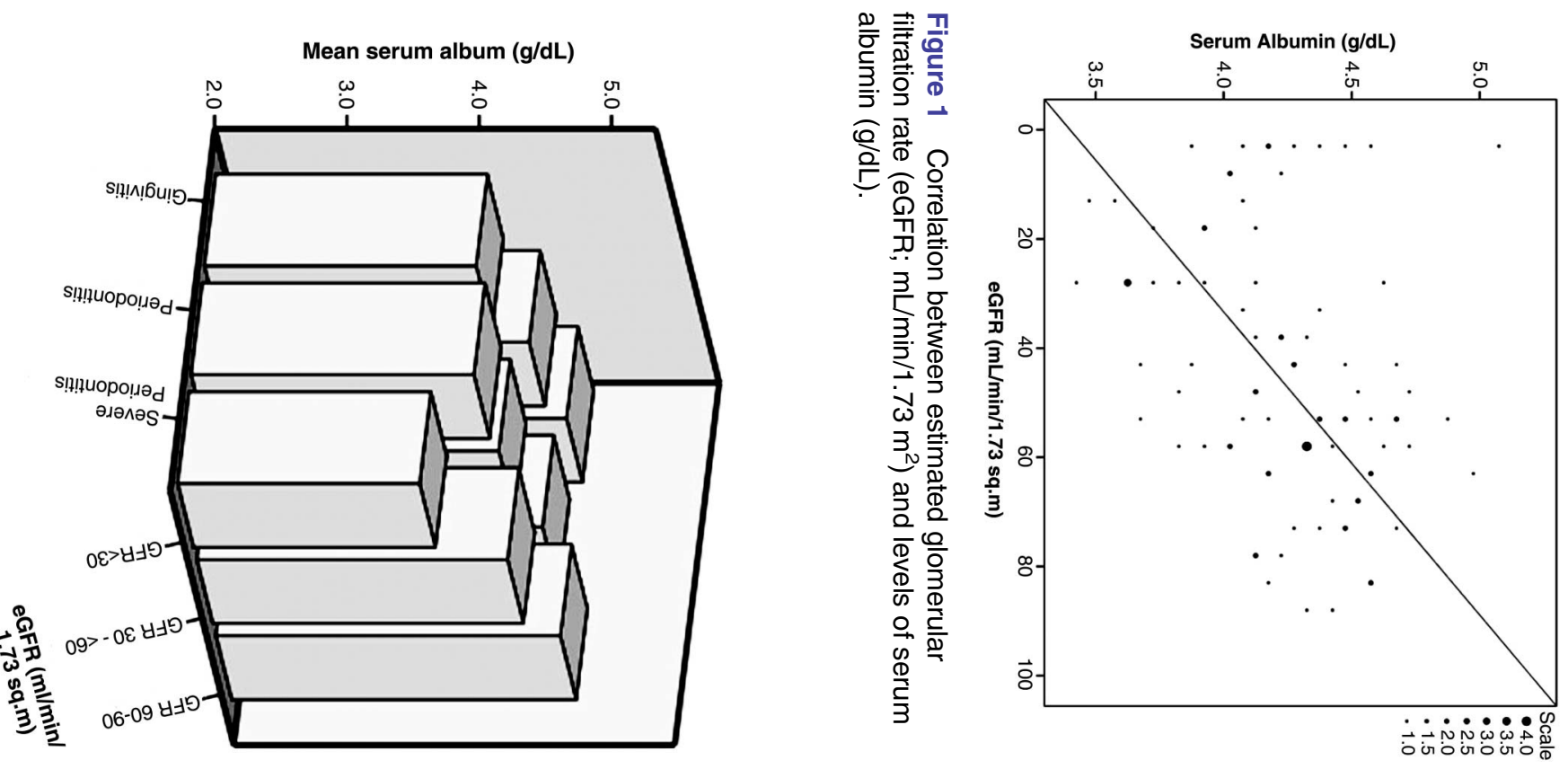

Table 2 Compare DMF index between group in $129 \mathrm{CKD}$ patients and according to the differences group of (Group 1: eGFR=60-90 mL/min/1.73 $\mathrm{m}^{2}$; Group 2: eGFR=30-60 mL/min $/ 1.73 \mathrm{~m}^{2}$; Group 3: eGFR $<30 \mathrm{~mL} / \mathrm{min} / 1.73 \mathrm{~m}^{2}$ )

\begin{tabular}{|c|c|c|c|c|c|c|c|c|c|c|}
\hline \multirow[b]{2}{*}{ Index } & \multicolumn{3}{|c|}{ Group 3 and 1 (control) } & \multicolumn{3}{|c|}{ Group 2 and 1 (control) } & \multicolumn{3}{|c|}{ Group $2+3$ and 1 (control) } & \multirow{2}{*}{$\begin{array}{l}\text { Group 1, } \\
2 \text { and } 3 \\
\text { p Value }\end{array}$} \\
\hline & Group 3 & Group 1 & p Value ${ }^{\star}$ & Group 2 & Group 1 & p Value ${ }^{\star}$ & Group 2+3 & Group1 & p Value ${ }^{\star}$ & \\
\hline Decay & $2(0,5)$ & $3(1,5)$ & 0.15 & $3.5(1,6.5)$ & $3(1,5)$ & 0.84 & $3(0,6)$ & $3(1,5)$ & 0.5 & 0.24 \\
\hline Missing & $10(4,19)$ & $8(5,13)$ & 0.75 & $13(8,17)$ & $8(5,13)$ & 0.01 & $12(6,19)$ & $8(5,13)$ & 0.046 & 0.05 \\
\hline Filling & $0(0,3)$ & $2.5(0,5)$ & 0.05 & $1(0,4)$ & $2.5(0,5)$ & 0.33 & $1(0,4)$ & $2.5(0,5)$ & 0.26 & 0.13 \\
\hline DMFT Index & $18(10,26)$ & $17.5(12,23)$ & 0.85 & $21(15.5,26.5)$ & $17.5(12,23)$ & 0.045 & $20(13,26)$ & $17.5(12,23)$ & 0.33 & 0.08 \\
\hline Remaining teeth & $14(6,22)$ & $14.5(9,20)$ & 0.83 & $11(5.5,16.5)$ & $14.5(9,20)$ & 0.046 & $12(6,19)$ & $14.5(9,20)$ & 0.347 & 0.08 \\
\hline
\end{tabular}

Values are median (25th percentile, 75th percentile).

*Mann-Whitney test.

tKruskal-Wallis test.

CKD, chronic kidney disease; DMFT, Decayed, Missing or Filled Teeth. 
periodontitis, and $29 \%$ had gingivitis. We also observed that the moderate CKD group (group 2) had less periodontitis than the severe and mild CKD groups (58\% vs $71 \%$ vs $63 \%$, respectively; $\mathrm{p}=0.47$ ) (table 3 ). The prevalences of severe periodontitis (CPI score of 4) of CKD groups 1, 2 and 3 were $9 \%, 25 \%$ and $23 \%$, respectively $(\mathrm{p}=0.11)$.

We also separated the 'more severe CKD' (eGFR $<60 \mathrm{~mL} / \mathrm{min} / 1.73 \mathrm{~m}^{2}$ ) and 'less severe CKD' (eGFR 60$90 \mathrm{~mL} / \mathrm{min} / 1.73 \mathrm{~m}^{2}$ ) groups. Eighty-three patients (64\%) were categorised into the more severe CKD group, and 46 patients (36\%) remained in the less severe CKD group. The mean ages of the more severe and less severe CKD groups were 62 and 60 years, respectively $(p=0.46)$. The serum albumin levels of the more severe CKD group were lower than those of the mild CKD group (4.17 and $4.42 \mathrm{~g} / \mathrm{L}$, respectively; $\mathrm{p}<0.001)$. Similarly, the haematocrit of the more severe CKD group was lower than that of the less severe CKD group ( $36 \%$ and $42 \%$, respectively; $\mathrm{p}<0.001$ ) (table 1 ).

The numbers of decayed teeth, filled teeth and normal remaining teeth were the same in the two groups (table 2). The more severe CKD group had marginally significantly more missing teeth than the mild CKD group (median 12 vs 8; $\mathrm{p}=0.046$ ). Severe periodontal disease was noticeably greater in the more severe CKD group than in the less severe CKD group, $24 \%$ vs $9 \%(\mathrm{p}=0.03)$ (table 3$)$.

Figure 2 shows that the mean levels of serum albumin declined and correlated with severe periodontal status and the poorest CKD group.

Ninety patients with CKD had collected serum albumin during this study. We analysed the association with various factors that might contribute to the low level of serum albumin (defined as $<3.8 \mathrm{~g} / \mathrm{dL}$ ). Lower albumin (figure 3) was associated with severe periodontitis status and eGFR $<30 \mathrm{~mL} / \mathrm{min} / 1.73 \mathrm{~m}^{2}$ (OR $(95 \%$ CI) 5.88 (1.64 to 21.11) and 5.80 (1.58 to 21.35), respectively). Brushing teeth more than once a day showed a negative association with hypoalbuminaemia (OR (95\% CI) 0.16 (0.05 to 0.60$)$ ).

\section{DISCUSSION}

In this study, periodontal diseases were more prevalent in patients with more severe CKD than in those with less severe CKD. In patients receiving MHD, poor periodontal health correlates with markers of malnutrition and inflammation. ${ }^{21}$ Albumin level, commonly used as a malnutrition marker, can predict mortality in both dialysis and post-kidney transplant patients. ${ }^{14}$ 30-33 The present study also demonstrates that serum albumin levels correlate with progressive stages of CKD $(\gamma=0.33 ; \mathrm{p}=0.002)$ and also decline with severe periodontal status (figure 2). Although previous studies ${ }^{21} 3435$ established that severe periodontitis is associated with low serum albumin in MHD patients, they did not include patients with early stages of CKD. Kshirsagar et $a l^{35}$ also reported on 154 MHD patients and confirmed that severe periodontitis was associated with low serum albumin (defined as $<3.5 \mathrm{mg} / \mathrm{dL}$ ). The present study reveals that severe periodontitis is associated with hypoalbuminaemia from the early stages of CKD.

Although there is significant overlap with inflammation, starvation and protein-energy wasting, no studies have confirmed the association between poor/reduced oral intake and hypoalbuminaemia. Starvation alone might not be enough to change serum markers such as serum albumin. ${ }^{35}$ Many studies support the association between systemic inflammatory markers, periodontitis and malnutrition in dialysis patients. ${ }^{8}$ 34 $36-38$ The Malnutrition Inflammation Score (MIS) was found to be a comprehensive scoring system with significant associations with prospective hospitalisation and mortality as well as measures of nutrition, inflammation and anaemia in MHD patients. $^{12}$ Several studies have reported that effective initial periodontal therapy might reduce systemic markers of inflammation such as

Table 3 Periodontaldiseases between group in 129 patients with CKD and according to the differences in group of CKD

\begin{tabular}{|c|c|c|c|c|c|c|c|c|c|c|}
\hline \multirow[b]{2}{*}{ Index } & \multicolumn{3}{|c|}{ Group 3 and 1 (control) } & \multicolumn{3}{|c|}{ Group 2 and 1 (control) } & \multicolumn{3}{|c|}{ Group $2+3$ and 1} & \multirow{2}{*}{$\begin{array}{l}\text { Group 1, } \\
2 \text { and } 3 \\
\text { p Valuet }\end{array}$} \\
\hline & $\begin{array}{l}\text { Group } 3 \\
(\mathrm{~N}=35)\end{array}$ & $\begin{array}{l}\text { Group } 1 \\
(\mathrm{~N}=46)\end{array}$ & $\begin{array}{l}\mathbf{p} \\
\text { Value }^{*}\end{array}$ & $\begin{array}{l}\text { Group } 2 \\
(\mathrm{~N}=48)\end{array}$ & $\begin{array}{l}\text { Group } 1 \\
(\mathrm{~N}=46)\end{array}$ & $\begin{array}{l}\text { p } \\
\text { Value }^{*}\end{array}$ & $\begin{array}{l}\text { Group 2+3 } \\
(\mathrm{N}=83)\end{array}$ & $\begin{array}{l}\text { Group } 1 \\
(\mathrm{~N}=46)\end{array}$ & $\begin{array}{l}\text { p } \\
\text { Value* }^{*}\end{array}$ & \\
\hline Gingivitis & $10(29 \%)$ & $17(37 \%)$ & 0.43 & $(42 \%)$ & $17(37 \%)$ & 34 & ) & $\%)$ & 3 & 17 \\
\hline Periodontitis & $25(71 \%)$ & $29(63 \%)$ & 0.43 & $8(58 \%)$ & $29(63 \%)$ & 0.64 & $3(64$ & 29 (63\%) & 3 & 17 \\
\hline $\begin{array}{l}\text { loderate } \\
\text { eriodontitis }\end{array}$ & 17 (49\%) & $25(54 \%)$ & 0.61 & $16(33 \%)$ & $25(54 \%)$ & 0.04 & $33(40 \%)$ & 25 (54\%) & 0.11 & 0.11 \\
\hline $\begin{array}{l}\text { Severe } \\
\text { periodontitis }\end{array}$ & $8(23 \%)$ & $4(9 \%)$ & 0.08 & $12(25 \%)$ & $4(9 \%)$ & 0.036 & $20(24 \%)$ & $4(9 \%)$ & 0.03 & 0.11 \\
\hline \multicolumn{11}{|c|}{$\begin{array}{l}\text { Group 1, eGFR=60-90 mL/min } / 1.73 \mathrm{~m}^{2} \text {; group 2, eGFR=30-60 mL/min } / 1.73 \mathrm{~m}^{2} \text {; group } 3 \text {, eGFR }<30 \mathrm{~mL} / \mathrm{min} / 1.73 \mathrm{~m}^{2} \text {. } \\
\text { The periodontal status was assessed using the CPI system. Periodontal health was transformed from the CPI score to fair (CPI score of } 1,2 \\
\text { or 5), moderate (CPI score of } 3 \text { ) or severe (CPI score of } 4 \text { ) periodontal status. Fair periodontal status was clinically diagnosed as gingivitis, } \\
\text { while moderate and severe periodontal statuses were clinically diagnosed as periodontitis. } \\
{ }^{*} \chi^{2} \text { test. } \\
\text { †Kruskal-Wallis test. } \\
\text { CKD, chronic kidney disease; CPI, Community Periodontal Index. }\end{array}$} \\
\hline
\end{tabular}


Figure 3 Forest plots of various factors that might contribute to hypoalbuminaemia.
Odd Ratios for Hypoalbuminemia (serum albumin $<3.8 \mathrm{~g} / \mathrm{dL}$ )

$$
\text { OR }(95 \% \text { CI })
$$

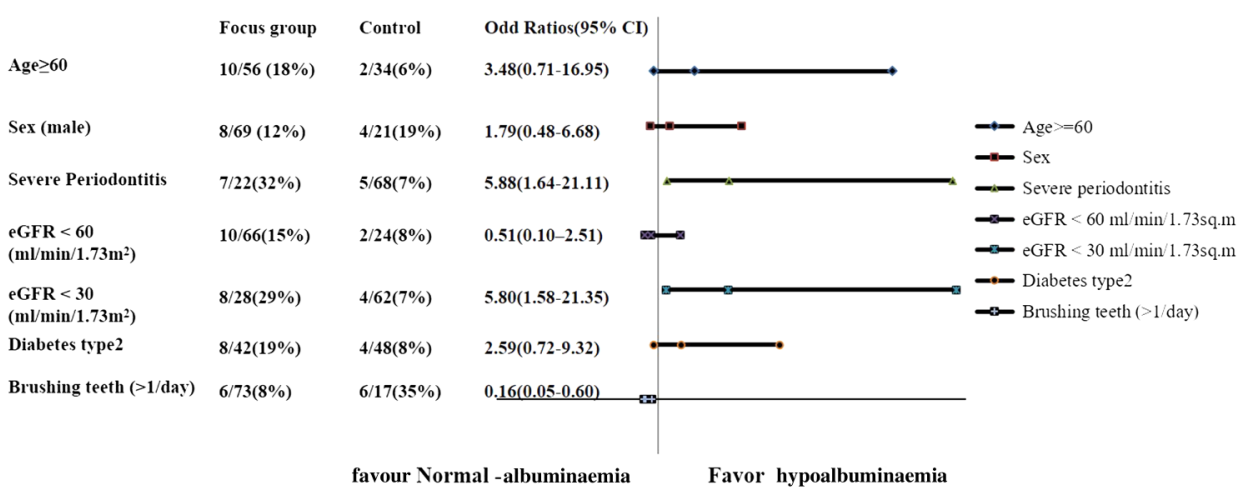

risk factor for periodontal disease, but periodontal disease also increases the severity of diabetes mellitus. Chronic infection and inflammation may amplify the advanced glycation end-product-mediated cytokine response in diabetes mellitus. ${ }^{50}$ This study did not show any association of a higher prevalence of poor periodontal status in CKD patients with than without diabetes mellitus. Chuang et $a \tilde{l}^{\tilde{1}}$ reported that patients with diabetic nephropathy had more caries than those with CKD of non-diabetic aetiology; however, our study did not confirm this. Bots $e t a p^{2}$ reported that the number of decayed teeth in patients receiving maintenance dialysis was similar to that of the healthy controls. With respect to the prevalence of fillings, Bayraktar et a $\tilde{l}^{53}$ established a lower index of restorations in a group of patients with advanced CKD who underwent haemodialysis than in a control group, although the difference was not statistically significant. Bots et $a \bar{l}^{2}$ also found no differences in the number of fillings between a group of patients with chronic renal failure who were on dialysis and a control group, although this series had certain limitations, specifically that they excluded patients under 25 or over 52 years of age and those with serious difficulties with travelling. ${ }^{23}$

The limitations of the present study include its performance in a single centre and a relatively small, but comparable with most previous reports, ${ }^{15} 1^{19} \quad 21 \quad 23$ number of enrolled patients. We could not consider the educational levels of these patients or their socioeconomic statuses, which might affect periodontal status. ${ }^{54}$ Moreover, we did not record other comorbidities such as malabsorption, which could cause hypoalbuminaemia. Despite submission of this study after the protocol had ended in 2012, it is contemporary because CKD guidelines were published during the same period. $^{55-57}$

The strengths of our study include: (1) a crosssectional study also demonstrating that serum albumin levels correlate with progressive stages of CKD and severe periodontal status; (2) uniform laboratory measurements because all the laboratory data were obtained from a single facility. 


\section{CONCLUSIONS}

Accounting for the immunity of patients with CKD, this study reveals that patients with more severe CKD have more severe periodontal disease than those with less severe CKD. Severe periodontitis is also associated with hypoalbuminaemia from the early stages of CKD. Routine dental examinations and proper preventive dental care are suggested for patients with CKD, especially in the early stages of the disease. A prospective cohort study needs to link the association of severe periodontitis, mortality and hypoalbuminaemia and confirm desirable survival outcome on successful treatment of periodontal diseases.

\section{Author affiliations}

${ }^{1}$ Medicine Division, Medical Department, Golden Jubilee Medical Center, Mahidol University, Nakhon Pathom, Thailand

${ }^{2}$ Department of Oral and Maxillofacial Radiology, Faculty of Dentistry, Mahidol University, Bangkok, Thailand

${ }^{3}$ Department of Oral Medicine and Periodontics, Faculty of Dentistry, Mahidol University, Bangkok, Thailand

${ }^{4}$ Medicine Department, Saraburi Hospital, Muang, Saraburi, Thailand

Acknowledgements We would like to express our sincere appreciation of the teammates in the medical and dental clinics of the Golden Jubilee Medical Center, Mahidol University, who work every day, not only to take care of patients, but also to ensure extensive data collection on which our work is based. We thank the International Center for Medical and Radiological Technology Laboratory Department for providing the clinical data, analysis and review for this research project and for advancing the knowledge and practice of kidney care.

Contributors RA and MR designed the study method and applied for ethics committee approval. SW provided article and manuscript revision. NR provided article and manuscript revision. SC provided dental examination for all patients. UU provided article and manuscript revision. MR wrote the manuscript and was the primary investigator for the study.

Funding This research received no specific grant from any funding agency in the public, commercial or not-for-profit sectors.

Competing interests None declared.

Patient consent Obtained.

Ethics approval This study was designed as a cross-sectional study and performed at Golden Jubilee Medical Center, Mahidol University, during 2011-2012. The project was approved by the Mahidol University Institutional Review Board (MU-IRB 2011/102.1005).

Provenance and peer review Not commissioned; externally peer reviewed.

Data sharing statement No additional data are available.

Open Access This is an Open Access article distributed in accordance with the Creative Commons Attribution Non Commercial (CC BY-NC 4.0) license, which permits others to distribute, remix, adapt, build upon this work noncommercially, and license their derivative works on different terms, provided the original work is properly cited and the use is non-commercial. See: http:// creativecommons.org/licenses/by-nc/4.0/

\section{REFERENCES}

1. De Rossi SS, Glick M. Dental considerations for the patient with renal disease receiving hemodialysis. J Am Dent Assoc 1996;127:211-19.

2. Ferguson CA, Whyman RA. Dental management of people with renal disease and renal transplants. $N Z$ Dent $J$ 1998;94:125-30.

3. Proctor R, Kumar N, Stein A, et al. Oral and dental aspects of chronic renal failure. J Dent Res 2005;84:199-208.

4. Schoolwerth AC, Engelgau MM, Hostetter TH, et al. Chronic kidney disease: a public health problem that needs a public health action plan. Prev Chronic Dis 2006;3:A57.
5. Levey AS, Coresh J, Balk E, et al. National Kidney Foundation practice guidelines for chronic kidney disease: evaluation, classification, and stratification. Ann Intern Med 2003;139:137-47.

6. Gelber RP, Kurth T, Kausz AT, et al. Association between body mass index and CKD in apparently healthy men. Am J Kidney Dis 2005;46:871-80.

7. Hamid MJ, Dummer CD, Pinto LS. Systemic conditions, oral findings and dental management of chronic renal failure patients: general considerations and case report. Braz Dent J 2006;17:166-70.

8. Kshirsagar AV, Moss KL, Elter JR, et al. Periodontal disease is associated with renal insufficiency in the Atherosclerosis Risk In Communities (ARIC) study. Am J Kidney Dis 2005;45:650-7.

9. Craig RG, Spittle MA, Levin NW. Importance of periodontal disease in the kidney patient. Blood Purif 2002;20:113-19.

10. Bayraktar G, Kurtulus I, Duraduryan A, et al. Dental and periodontal findings in hemodialysis patients. Oral Dis 2007;13:393-7.

11. Gavalda C, Bagan J, Scully C, et al. Renal hemodialysis patients: oral, salivary, dental and periodontal findings in 105 adult cases. Oral Dis 1999;5:299-302.

12. Rattanasompattikul M, Molnar MZ, Zaritsky JJ, et al. Association of malnutrition-inflammation complex and responsiveness to erythropoiesis-stimulating agents in long-term hemodialysis patients. Nephrol Dial Transplant 2013;28:1936-45.

13. Rattanasompattikul M, Chanchairujira K, On-Ajyooth L, et al. Evaluation of atherosclerosis, arterial stiffness and related risk factors in chronic hemodialysis patients in Siriraj Hospital. J Med Assoc Thai 2011;94(Suppl 1):S117-24.

14. Summers SA, Tilakaratne WM, Fortune $F$, et al. Renal disease and the mouth. Am J Med 2007;120:568-73.

15. Ruospo M, Palmer SC, Craig JC, et al. Prevalence and severity of oral disease in adults with chronic kidney disease: a systematic review of observational studies. Nephrol Dial Transplant 2014;29:364-75.

16. Bots $\mathrm{CP}$, Brand $\mathrm{HS}$, Poorterman $\mathrm{JH}$, et al. Oral and salivary changes in patients with end stage renal disease (ESRD): a two year follow-up study. Br Dent J 2007;202:E3.

17. Thorman R, Neovius M, Hylander B. Clinical findings in oral health during progression of chronic kidney disease to end-stage renal disease in a Swedish population. Scand J Urol Nephrol 2009;43:154-9.

18. Grubbs V, Vittinghoff $\mathrm{E}$, Taylor $\mathrm{G}$, et al. The association of periodontal disease with kidney function decline: a longitudinal retrospective analysis of the MrOS dental study. Nephrol Dial Transplant 2016;31:466-72.

19. Borawski J, Wilczynska-Borawska M, Stokowska W, et al. The periodontal status of pre-dialysis chronic kidney disease and maintenance dialysis patients. Nephrol Dial Transplant 2007;22:457-64.

20. Ioannidou $\mathrm{E}$, Hall $\mathrm{Y}$, Swede $\mathrm{H}$, et al. Periodontitis associated with chronic kidney disease among Mexican Americans. J Public Health Dent 2013;73:112-19.

21. Chen LP, Chiang CK, Chan CP, et al. Does periodontitis reflect inflammation and malnutrition status in hemodialysis patients? Am $J$ Kidney Dis 2006;47:815-22.

22. Sobrado Marinho JS, Tomas Carmona I, Loureiro A, et al. Oral health status in patients with moderate-severe and terminal renal failure. Med Oral Patol Oral Cir Bucal 2007;12:E305-10.

23. Naugle K, Darby ML, Bauman DB, et al. The oral health status of individuals on renal dialysis. Ann Periodontol 1998;3:197-205.

24. Anand N, CC S, Alam MN. The malnutrition inflammation complex syndrome: the missing factor in the perio-chronic kidney disease interlink. J Clin Diagn Res 2013;7:763-7.

25. Ioannidou E, Swede H, Dongari-Bagtzoglou A. Periodontitis predicts elevated C-reactive protein levels in chronic kidney disease. J Dent Res 2011;90:1411-15.

26. Levey AS, Bosch JP, Lewis JB, et al. A more accurate method to estimate glomerular filtration rate from serum creatinine: a new prediction equation. Modification of Diet in Renal Disease Study Group. Ann Intern Med 1999;130:461-70.

27. Ditmyer M, Dounis G, Mobley C, et al. Inequalities of caries experience in Nevada youth expressed by DMFT index vs. Significant Caries Index (SiC) over time. BMC Oral Health 2011;11:12.

28. Shizukuishi S, Hayashi N, Tamagawa $\mathrm{H}$, et al. Lifestyle and periodontal health status of Japanese factory workers. Ann Periodontol 1998;3:303-11.

29. Coresh J, Astor BC, McQuillan G, et al. Calibration and random variation of the serum creatinine assay as critical elements of using equations to estimate glomerular filtration rate. Am J Kidney Dis 2002:39:920-9.

30. Kim Y, Molnar MZ, Rattanasompattikul M, et al. Relative contributions of inflammation and inadequate protein intake to hypoalbuminemia in patients on maintenance hemodialysis. Int Urol Nephrol 2013;45:215-27. 
31. Kalantar-Zadeh K, Kilpatrick RD, Kuwae N, et al. Revisiting mortality predictability of serum albumin in the dialysis population: time dependency, longitudinal changes and population-attributable fraction. Nephrol Dial Transplant 2005;20:1880-8.

32. Molnar MZ, Kovesdy CP, Bunnapradist S, et al. Associations of pretransplant serum albumin with post-transplant outcomes in kidney transplant recipients. Am J Transplant 2011;11:1006-15.

33. Kalantar-Zadeh K, Kopple JD. Relative contributions of nutrition and inflammation to clinical outcome in dialysis patients. Am J Kidney Dis 2001;38:1343-50.

34. Wehmeyer MM, Kshirsagar AV, Barros SP, et al. A randomized controlled trial of intensive periodontal therapy on metabolic and inflammatory markers in patients With ESRD: results of an exploratory study. Am J Kidney Dis 2013;61:450-8.

35. Kshirsagar AV, Craig RG, Beck JD, et al. Severe periodontitis is associated with low serum albumin among patients on maintenance hemodialysis therapy. Clin J Am Soc Nephrol 2007;2:239-44.

36. Cengiz MI, Bal S, Gokcay S, et al. Does periodontal disease reflect atherosclerosis in continuous ambulatory peritoneal dialysis patients? J Periodontol 2007;78:1926-34

37. Ismail G, Dumitriu HT, Dumitriu AS, et al. Periodontal disease: a covert source of inflammation in chronic kidney disease patients. Int J Nephrol 2013;2013:515796.

38. Tonetti MS, D'Aiuto F, Nibali L, et al. Treatment of periodontitis and endothelial function. N Engl J Med 2007;356:911-20.

39. Ebersole JL, Machen RL, Steffen MJ, et al. Systemic acute-phase reactants, C-reactive protein and haptoglobin, in adult periodontitis. Clin Exp Immunol 1997;107:347-52.

40. D'Aiuto F, Parkar M, Andreou G, et al. Periodontitis and systemic inflammation: control of the local infection is associated with a reduction in serum inflammatory markers. J Dent Res 2004;83:156-60.

41. D'Aiuto F, Nibali L, Parkar M, et al. Short-term effects of intensive periodontal therapy on serum inflammatory markers and cholesterol. $J$ Dent Res 2005;84:269-73.

42. D'Aiuto F, Parkar M, Nibali L, et al. Periodontal infections cause changes in traditional and novel cardiovascular risk factors: results from a randomized controlled clinical trial. Am Heart J 2006;151:977-84.

43. Kshirsagar AV, Grubbs V. Periodontal disease and CKD-associated morbidity: is there now enough evidence to move from observation to intervention? Am J Kidney Dis 2015;66:181-3.
44. Chen YT, Shih CJ, Ou SM, et al. Periodontal disease and risks of kidney function decline and mortality in older people: a community-based cohort study. Am J Kidney Dis 2015;66:223-30.

45. Machowska A, Carrero JJ, Lindholm B, et al. Therapeutics targeting persistent inflammation in chronic kidney disease. Transl Res 2016;167:204-13.

46. Rix $M$, Andreassen $\mathrm{H}$, Eskildsen $\mathrm{P}$, et al. Bone mineral density and biochemical markers of bone turnover in patients with predialysis chronic renal failure. Kidney Int 1999;56:1084-93.

47. Torrungruang K, Tamsailom S, Rojanasomsith K, et al. Risk indicators of periodontal disease in older Thai adults. J Periodontol 2005;76:558-65.

48. Oliver RC, Brown LJ, Loe H. Periodontal diseases in the United States population. J Periodontol 1998;69:269-78.

49. Loe $\mathrm{H}$. Periodontal disease. The sixth complication of diabetes mellitus. Diabetes Care 1993;16:329-34.

50. Grossi SG, Genco RJ. Periodontal disease and diabetes mellitus: a two-way relationship. Ann Periodontol 1998;3:51-61.

51. Chuang SF, Sung JM, Kuo SC, et al. Oral and dental manifestations in diabetic and nondiabetic uremic patients receiving hemodialysis. Oral Surg Oral Med Oral Pathol Oral Radiol Endod 2005;99: 689-95.

52. Bots CP, Poorterman JH, Brand HS, et al. The oral health status of dentate patients with chronic renal failure undergoing dialysis therapy. Oral Dis 2006;12:176-80.

53. Bayraktar G, Kazancioglu R, Bozfakioglu S, et al. Evaluation of salivary parameters and dental status in adult hemodialysis patients. Clin Nephrol 2004;62:380-3.

54. Grubbs V, Plantinga LC, Crews DC, et al. Vulnerable populations and the association between periodontal and chronic kidney disease. Clin J Am Soc Nephrol 2011;6:711-17.

55. Levin A, Stevens PE. Summary of KDIGO 2012 CKD Guideline: behind the scenes, need for guidance, and a framework for moving forward. Kidney Int 2014:85:49-61.

56. Stevens PE, Levin A, Kidney Disease: Improving Global Outcomes Chronic Kidney Disease Guideline Development Work Group M. Evaluation and management of chronic kidney disease: synopsis of the kidney disease: improving global outcomes 2012 clinical practice guideline. Ann Intern Med 2013;158:825-30.

57. Levin A, Stevens PE. The authors reply. Kidney Int 2013;84:623. 